\title{
Public Space, Urban Identity and Conflict in Medieval Flanders
}

\section{Michael Sokolowski}

Ideas of public space can say a lot about the societies that create them. A clear example of this was its use in Flanders during the medieval period. People within Flanders found themselves in a unique situation having one of the highest amounts of urban densities in Europe. This allowed for a distinct urban identity emerge. Within the urban centres of Flanders a distinct political culture had been fostered which caused many examples of conflict within cities themselves and against the nobility of Flanders, France and Burgundy. By looking at examples of these conflicts a distinct urban identity appears. This urban identity allowed public space to be used as a tool by the people of Flanders in order to protect their political rights and liberties. To see the use of public spaces as a tool Henri Lefebvre's theory of the construction of public space must be understood. Once Lefebvre's theories are understood specific spaces may be looked at in order to see what role they played in the urban identity of the Flemish cities and how theses identities wrapped up in public spaces were used as tools during times of conflict, revolt and rebellion. The spaces that provided the best examples of this were the distinct borders of towns defined by walls and defences, belfries and marketplaces.

The most influential scholar with regards to theories of public space was Henri Lefebvre. His book The Production of Space discussed the relationship of space to the capitalist process. His main argument in The Production of Space was that "between the sixteenth and the twentieth century, the fundamental acts of reproduction (of bio-logical life, of labor power, and of the social relations of production) necessary to capitalism occurred in a space that was at once physical and ideological. In fact, these acts depended on the existence of this space for their realization". ${ }^{1}$ Henri Lefebvre argued ideology and power relations were present in space and were often represented by structures such as buildings, monuments, and public art. Lefebvre developed three main concepts that governed ideas of public space; spatial practice, representation of space, and representational space. The first concept, spatial practice, centred on ideas "which embrac[ed] production and reproduction, and the particular locations and spatial sets characteristic of each social formation. Spatial practice ensur[ed] continuity and some degree of cohesion". ${ }^{2}$ This meant that people within a given location recognized that certain functions were performed in a specific place with a specific purpose. Lefebvre highlighted that there was a link "between daily reality (daily routine) and urban reality (the routes and networks which link up the places set aside for work, private life leisure)". ${ }^{3}$ The second concept that Lefebvre argued was "representations of space". By "representations of space" Lefebvre meant the characteristics that physically defined space. These were the organizational factors such as boundaries and borders that were created and defined by

\footnotetext{
${ }^{1}$ Peter Arnade, Martha Howell and Walter Simons. "Fertile Spaces: The Productivity of Urban Space in Northern Europe." The Journal of Interdisciplinary History, 32, 4 (Spring, 2002), 517

${ }^{2}$ Henri Lefebvre. The Production of Space. (Oxford UK \& Cambridge USA: Blackwell, 1991), 33

${ }^{3}$ Ibid, 38
} 
people such as scientists, urban planners, social engineers, urbanists and technocratic subdividers. ${ }^{4}$ Representations of space were important because for a particular space to have meaning it needed defined boundaries of where it started and ended. This was because it needed to have a distinct location where people could gather and take part in the actions performed in the space. The final concept highlighted by Lefebvre was "representational space" which was how space embodied symbols (in plain sight or hidden) that represented an "underground social life". Representational space highlighted how the ideas of certain spaces, which were "lived through", were associated to certain images or spaces. ${ }^{5}$ This was how certain public spaces were encoded with ideologies and given specific meanings within given communities.

Lefebvre applied his theories of public space to periods well after the medieval period, most notably between the sixteenth and twentieth centuries. This can be seen as part of a fallacy in which many sociologists and scholars dismiss the medieval period as being a simple society governed by feudalism. In fact Lefebvre's theories can be clearly seen governing many of the spaces which were at the heart of the medieval city. This means that Lefebvre's theories can be used to understand how public space represented the identity of many medieval urban centres. One such example of this was the creation of government in the English city of Ipswich. While Ipswich was not within Flanders, public space was used similarly in both places so the assumption can be made that the distinct meanings of public spaces developed similarly in both locations. In the account of the setting up the selfgovernment of Ipswich the entire town met in the churchyard of St. Mary at Tower to practice politics in the form of the election of members of government and the creations of their town charter. Numerous times during the creation of its government the town was dismissed and told to reassemble at a later date. ${ }^{6}$ This showed that it was the knowledge of all the residents of Ipswich that politics were performed in the church yard. This was an example of Lefebvre's concept of spatial practice. The second of Lefebvre's concepts, "the representations of space" can be seen in the fact that the church yard was a defined space. The church yard itself would have had a solidified border known by all members of Ipswich and developed through agreements between the town, the clergy of St. Mary at Tower and the nobility. Finally, by the town practicing politics within the church yard, a sense of its importance would have begun to emerge within the people of Ipswich. The space would become a representation of the town's political identity and ideology. This was Lefebvre's final concept: "representational space". The fact that all three of Lefebvre's concepts of public space could be seen in the account from Ipswich showed that indeed Lefebvre`s theory of the creation of public space was present in the medieval period. This means that events in and around Flanders can highlight how the urban centres of Flanders used their identity and understanding of public space during times of conflict as a distinct tool.

The urban identity of the cities of Flanders was found within the creation of public space and the construction of buildings in these public spaces. The construction of spaces and buildings such as markets, belfries and town defences all had a distinct roll in the development of urban identity. The understanding of what role a space or a building played

\footnotetext{
${ }^{4}$ Ibid

${ }^{5}$ Ibid 33-38

${ }^{6}$ Account of the setting up of self-government of Ipswich (1201) http://users.trytel.com/ tristan/towns/ ipswich2.html (Accessed Nov 15, 2013)
} 
in everyday life ensured there was a connection between those structures and the identity people who used them. This connection can be seen by the presence distinct buildings on city seals. ${ }^{7}$ The significance of this was that a city's seal was crucial to its political existence. The presence of a seal would legalize documents and signify where letters or legislation came from. The fact that a building would show up on a town seal would speak of how a city defined itself and the importance of the building on the seal. The use of public space can be seen as having a direct relationship with power. According to Marc Boone, "Urban space offered urban factions concrete sites for consolidating power relations among themselves and staging, often theatrically, the conflicts between the city and its princely rivals". ${ }^{8}$ This meant that the use of public space and conflict were inseparable. By understanding the importance of public space in Flanders specific spaces and structures, such as town borders marked by walls, the marketplace and belfries can be looked at in more detail in order to understand their importance to the cities they were found in. By identifying these spaces, their use during conflict by the Flemish people can be highlighted and understood.

Ultimately the biggest public space within the cities of Flanders was their borders often marked by walls or defences. The borders of a city defined the sphere of influence of that community. The people who resided within a town's borders felt that they had a legitimate role within things such as economics and politics. A city's ability to control who entered its borders was important because it illustrated how residents perceived their independence and autonomy within their distinct space. Unwelcomed entrance within a city's borders was perceived as a direct attack against the city. A clear example of this was illustrated during the Bruges rebellion of 1436-1438 during which Philip the Good requested permission to pass through the city's lands with his army. The city refused and requested that Philip take his army around. When Philip did not do this the city of Bruges perceived it as an attack on their rights and liberties. ${ }^{9}$ The significance of a city's borders and its ability to control who entered can be also seen during many civic rituals and ceremonies such as the "Rulers Advent". The Rulers Advent was a new ruler's ceremonial first entrance into his most influential cities. The ceremony had particular political ramifications. The ceremony signified both the cities submission to its new ruler and the new ruler's recognition of the cities rights and liberties. ${ }^{10}$ This ceremony showed a distinct understanding by the people within cities of what their sphere of influence was and the distinct physical space in which they possessed their rights and liberties. This understanding formed a distinct urban identity specific to the populations of each Flemish city.

In times of conflict a city's borders and walls became a valuable tool used by its residents. During times of revolt and rebellion the control of a town's borders and the

\footnotetext{
${ }^{7}$ Marc Boone. "Urban Space and Political conflict in Late Medieval Flanders." The Journal of Interdisciplinary History 32, 4 (2002), 627

${ }^{8}$ Ibid, 623

9 Jan Dumolyn.“The 'Terrible Wednesday' of Pentecost: Confronting Urban and Princely Discourses in the Bruges Rebellion of 1436-1438," History. 92, 305, (Jan 2007), 11

10 James M. Murray. "The Liturgy of the Count's Advent in Bruges, from Galbert to Van Eyck. In City and Spectacle in Medieval Europe. Eds Barbra A. Hanawalt \&Kathryn L. Reyerson, (Minneapolis \& London: University of Minisota Press, 1994), 140-141
} 
defenses became a crucial tool which represented both defiance and submission. This can clearly be seen during the revolt of Bruges and Ghent in 1301. During the revolt James of Saint-Pol ordered that the fortifications of Bruges be torn down. However, the leader of the revolt, Peter the King, publicly forbade these orders. ${ }^{11}$ The act of refusing to take down the city's fortification was a direct act of defiance that symbolized Bruges's autonomy. If the people of Bruges would have followed James of Saint-Pol's orders it would have been perceived by the people Bruges and the surrounding Flemish cities as an act of submission. Without the towns fortifications it would have been left defenseless and would have had to rely on the Count of Saint-Pol for protection and defense. The fact that Peter the King forbade these orders publicly was a clear act of defiance. It symbolized that the people of Bruges were capable of their own defence and were ultimately in control of their city. If the count of Saint-Pol wished to re-enter the city he would have to recognize the city's grievances. This act would have been used as a tool to legitimize both the actions the people of Bruges had undertaken as well as their reasons for revolt. The ability to control who entered and left a city was also important during times of revolt. This fact can clearly be seen during a tax revolt in Tournai in 1365. While Tournai was outside of Flanders it can be assumed the importance of a city's borders and walls symbolized similar things due to the fact that revolts and rebellions were very similar in Flanders and Northern France. During the tax revolt the people of Tournai made a distinct effort to gain control of the city's walls and its entrances and exits. During the revolt the people of Tournai "were able to get all the keys to the gates and [hand] them over to one of their comrades to guard in order not to let anyone leave the city without their knowledge".12 By controlling the gates, the people of Tournai would have been able to control who entered and exited the city. This fact asserted it was the people of Tournai that controlled the city and it was their right to control what happened within its borders. Both of these examples point to the important ways in which Flemish cities used their borders and walls, during times of conflict and revolt, in order to display and protect their identity.

Belfries were an example of second important public space directly connected to the cities of Flanders unique sense of identity. Belfries were important to life within Flemish towns. They were not only central to guild culture within cities, but were also a symbol of the power of urban communities. They were often at the heart of the political identity of Flemish cities. This was due to the fact that belfries often housed the archives of the city which contained charters which defined its rights, liberties and privileges. ${ }^{13}$ Belfries also played a significant part in the development of the public sphere. Not only did they dominate the soundscape of Flemish cities, they also provided important ways in which the town elite were able to communicate with the people of their city. Belfries often called people for meetings and delivered important messages to large populations throughout the

\footnotetext{
${ }^{11}$ Annales Gandenses, ed. Hilda Johnstone (London, 1951), 16-18. in Popular Protest in Late Medieval Europe, ed.Samuel K. Chon Jr, (Manchester: Manchester University Press, 2004), 26

${ }^{12}$ Chronique des Pays-Bas, de France, etc in Corpus Chronicorum Flandriae, ed. J.-J. de Smet, vol III (Brussels, 1856), pp. 207-9 in Popular Protest in Late Medieval Europe, ed.Samuel K. Chon Jr, (Manchester: Manchester University Press, 2004), 98

13 Peter Arnade. "Crowds, Banners and the Marketplace: Symbols of Defiance and Defeat During the Ghent War of 1452-1453." Journal of Medieval and Renaissance Studies, 24, 3 (1994), 479
} 
city. ${ }^{14}$ Belfries were also crucial to the ritualistic life of many Flemish towns. Many important ceremonies would start and finish with the ringing of bells in order to summon and then disperse the people attending. These callings would be recognized by all people within the city. ${ }^{15}$ Belfries were also a symbol of a faction's power within Flemish cities. The influence and power of various factions within the city were represented by the size and volume of their belfry. These factors were directly related to how many people its messages could reach. If a faction did not have a belfry they were ultimately powerless because they had no voice within the public sphere of the city. ${ }^{16}$ Belfries were also a source of power because they controlled the time within the cities they were located. For many people the only way they were able to measure the passing of time was from the ringing of the various bells of the city. ${ }^{17}$ The ability to control time allowed its controller a great amount of power over its population. Most importantly belfries fostered a sense of communal identity within Flemish cities. The ringing of the bells was often only understood by people from that area. The ringing fostered a localized language from which people gained a sense of community. ${ }^{18}$ It would be this fact that proved to be the most valuable during times of revolt and conflict.

Belfries often played a significant part during times of revolt and conflict. They were often used as a tool by which the leaders of revolts and conflicts were able to communicate with their followers in a way in which only they could understand. The ringing of bells would often signal when to commence and halt action, making belfries the earliest targets of rebels and protesters. ${ }^{19}$ Once again the tax revolt in Tournai provided a descriptive example of the importance of belfries. During the revolt the people of Tournai being unable to capture Master Pierre d'Orgimont, immediately returned to the belfry to signal for the people of the city to assemble and arm themselves in preparation for conflict. Upon arriving at the belfry they found the cord cut which forced them to ring the emergency and curfew bells. ${ }^{20}$ This account was rich with examples of how important belfries were during times of revolt. The fact that one of the first things the rebels did was go to the belfry illustrates the crucial part that belfries played in revolts. The only way the rebels were able to call the people to arms was by ringing the bells of the belfry. The action of the cord to the bells being cut by the elites spoke to the importance of belfries as well. The fact that the elites took the time to cut the cord of the belfry before they left shows how important they felt this action was. This action shows they hoped to silence the leaders of the revolt by preventing them from communicating with the people of Tournai. The example of Tournai

\footnotetext{
14 Carol Symes. "Out in the Open, in Arras: Sightlines, Soundscapes and the Shaping of a Medieval Public Sphere," in Cities, Texts and Social Networks 400-1500. Experiences and Perceptions of Medieval Urban Space, eds. Caroline Goodson, Anne E. Lester, and Carol Symes (Fanham UK: Ashgate, 2010), 297

${ }^{15}$ Gerard Nijsten. "The Duke and His Towns: The Power of Ceremonies, Feasts, and Public Amusement in the Duchy of Guelders (East Netherlands) in the Fourteenth and Fifteenth Centureies." in City and Spectacle in Medieval Europe. Eds Barbra A. Hanawalt \&Kathryn L. Reyerson, (Minneapolis \& London: University of Minisota Press, 1994), 259

16 Boone. "Urban Space and Political conflict in Late Medieval Flanders.", 629

${ }^{17}$ Symes, "Out in the Open, in Arras, 297

18 Boone. "Urban Space and Political conflict in Late Medieval Flanders.",629

${ }^{19}$ Symes, "Out in the Open, in Arras, 298

${ }^{20}$ Chronique des Pays-Bas, de France, etc in Corpus Chronicorum Flandriae, 97
} 
also demonstrates the distinct language vocalized by the bells. The account described two distinct bells, the emergency bell (bancloqque) and the curfew bells (Wingeron). ${ }^{21}$ This illustrates a distinct language, which all the people of Tournai understood and listened to. This highlights a distinct public sphere, which the population of Tournai belonged to. The bells utilized the distinct identity the people of Tournai had which allowed them to become a tool used during times of conflict. Once again although Tournai falls outside of Flanders it could be assumed that because of its close proximity to Flanders and its similar development the example of Tournai was representative of similar events in Flanders.

The marketplace was not only an important public space within medieval Flemish cities but also the heart of economic and political life. Every town charter contained in it a provision to set up a market place and most allocated space at the centre of the city to house the market. ${ }^{22}$ Charters emphasised the market because it was directly tied to the economic prosperity of Flemish cities. This economic prosperity was a large part of how cities defined themselves because many of their distinct privileges were based on their strong economies and ability to provide finances to the nobility. The market place was also at the heart of guild culture within medieval towns. An example of this was the Great Market of Bruges which housed wooden stages where the deans of each guild were able to meet and discuss politics. There they were able to speak freely and bring forward grievances without fear of reprisal from the urban rulers of Flanders. ${ }^{23}$ The market was also a central place of assembly. It was where people of all social rankings would interact in order to formalize both political and cultural acts. For this reason the ability to manage its use was critical to the political control of the city. ${ }^{24}$ Finally the market was the main space where people of all levels of society were able to interact and exchange ideas. It was the market where people were most susceptible to both commercial and political messages making it key to the development of the public sphere within Flemish cities. ${ }^{25}$ In the market place Lefebvre's concepts of public space were very apparent. The market was a space which many people gathered to perform daily tasks (Spatial Practice) and the space where it was to be built was often allocated by charters at the centre of the town (Representation of Space). The market became a representational space when the people of Flemish cities practiced politics within it, which transformed the market from an inanimate space to one, filled with the political ideologies of the city. The market place became a key part of the urban identity of Flemish cities. This made it an important tool during periods of conflict and revolt.

During conflict and revolt the marketplace became a centre for organization and communication. This was because the market was a central place where many revolts could be controlled from. An example of this was during the revolt of Bruges 1299-1302 the Flemish people when they found a Frenchman would either kill them or take them to the

\footnotetext{
${ }^{21}$ Ibid

${ }^{22}$ Norman Pounds. The Medieval City. (Westport Connecticut \& London: Greenwood Press, 2005), 12 \& 126-127

${ }^{23}$ Christian. D Liddy and Jelle Haemars. "Popular Politics in the Late Medieval City: York and Bruges," English Historical Review. 128, 533 (2013),784

${ }^{24}$ Arnade. "Crowds, Banners and the Marketplace", 480-483

${ }^{25}$ Symes, Carol. "Out in the Open, in Arras", 291-292
} 
market. ${ }^{26}$ The automatic nature of the people of Bruges to take prisoners to the market spoke to its significance within minds of the people. The market during revolts was the obvious place to put people on trial because the market was the heart of the Bruges's identity and justice handed out from there would have been perceived as being on behalf of the entire city. The marketplace was also a key tool during guild conflicts and protests. This was illustrated in Matteo Villani's account of an internecine artisan conflict in Bruges and its resolution in 1359. After a perceived grievance the members of the cobbler guild marched on the marketplace in protest. There they were met by members of the weaver and fuller guilds and a conflict ensued. ${ }^{27}$ This account was rich with the significant meaning of the marketplace during times of protest. The automatic nature of the cobblers to march on the market showed that they understood its importance to the city and how they could use it as tool in their protest. They understood that if they took up the space of the market place their grievances would be heard. This was because it would halt the daily economic activity of the city. By the response of the fullers and the weavers it became apparent that the city did indeed take note of the cobbler's grievances. After the clash between guilds a member of the cobbler guild was chosen as one of the members of the ruling council of the city. ${ }^{28}$ This showed that the cobblers use of the market place had in fact succeeded in having their grievances heard gaining them more prominence in city politics. This spoke to just how important of a tool the market place was during times of conflict.

The use of public space helped define the characteristics of medieval Flanders. Spaces such as town borders, belfries and the marketplace all played key parts in the identity of Flemish cities. The people of Flanders intricate understanding of the importance and meaning of each of these spaces allowed for them to become important tools during times of revolt and conflict. This can be easily seen by looking at the significance of each of these spaces and the role they played in everyday life. With an understanding of this their uses during times of conflict can illuminate the distinct culture and identity of medieval Flemish cities.

\footnotetext{
${ }^{26}$ Giovanni Villani. Nuova Cronica. Ed. Giuseppe Pota, 3 vols. (Parma, 1990-91), II: Book Nine, chapter LV, 88-90 in Popular Protest in Late Medieval Europe, ed.Samuel K. Chon Jr, (Manchester: Manchester University Press, 2004), 30

27 Matteo Villani. Cronica con la continuazione di Filippo Villani ed. Porta (Parma, 1995), 2 vols II, Book Nine, chapter XXXVIII, pp. 338-40(1359) in Popular Protest in Late Medieval Europe, ed. Samuel K. Chon Jr. (Manchester: Manchester University Press, 2004), 95

${ }^{28}$ Ibid
} 
Sokolowski, "Public Space," 54

\section{Bibliography}

Account of the setting up of self-government of Ipswich (1201): http://users.trytel.com/ $\sim$ tristan/towns/ipswich2.html (Accessed Nov 15, 2013)

Annales Gandenses, ed. Hilda Johnstone (London, 1951), 16-18. in Popular Protest in Late Medieval Europe, ed.Samuel K. Chon Jr, 26-27. Manchester: Manchester University Press, 2004

Arnade, Peter. "Crowds, Banners and the Marketplace: Symbols of Defiance and Defeat During the Ghent War of 1452-1453." Journal of Medieval and Renaissance Studies, 24, 3 (1994), 471-497.

Arnade, Peter, Howell, Martha \& Simons, Walter. "Fertile Spaces: The Productivity of Urban Space in Northern Europe." The Journal of Interdisciplinary History, 32, 4 (Spring, 2002), 515-548.

Boone, Marc. "Urban Space and Political conflict in Late Medieval Flanders." The journal of Interdisciplinary History, 32, 4 (2002), 621-640

Chronique des Pays-Bas, de France, etc in Corpus Chronicorum Flandriae, ed. J.-J. de Smet, vol III (Brussels, 1856), pp. 207-9 in Popular Protest in Late Medieval Europe, ed.Samuel K. Chon Jr, 96-98. Manchester: Manchester University Press, 2004.

Dumolyn, Jan. “The 'Terrible Wednesday' of Pentecost: Confronting Urban and Princely Discourses in the Bruges Rebellion of 1436-1438," History. 92, 305, (Jan 2007), 3-20

Lefebvre, Henri. The Production of Space. Oxford UK \& Cambridge USA: Blackwell, 1991

Liddy Christian. \& Haemars, Jelle. "Popular Politics in the Late Medieval City: York and Bruges," English Historical Review. 128, 533 (2013), 771-804

Murray, James M. “The Liturgy of the Count's Advent in Bruges, from Galbert to Van Eyck. In City and Spectacle in Medieval Europe. Eds Barbra A. Hanawalt \&Kathryn L. Reyerson, 137-152. Minneapolis \& London: University of Minisota Press, 1994.

Nijsten, Gerard. "The Duke and His Towns: The Power of Ceremonies, Feasts, and Public Amusement in the Duchy of Guelders (East Netherlands) in the Fourteenth and Fifteenth Centureies." in City and Spectacle in Medieval Europe. Eds Barbra A. Hanawalt \&Kathryn L. Reyerson. 235-270. Minneapolis \& London: University of Minisota Press, 1994.

Pounds, Norman. The Medieval City. Westport Connecticut \& London: Greenwood Press, 2005. 
Symes, Carol. "Out in the Open, in Arras: Sightlines, Soundscapes and the Shaping of a Medieval Public Sphere," in Cities, Texts and Social Networks 400-1500. Experiences and Perceptions of Medieval Urban Space. eds. Caroline Goodson, Anne E. Lester, and Carol Symes. 279-302. Fanham UK: Ashgate, 2010.

Villani, Giovanni. Nuova Cronica. Ed. Giuseppe Pota, 3 vols. (Parma, 1990-91), II: Book Nine, chapter LV, 88-90 in Popular Protest in Late Medieval Europe, ed.Samuel K. Chon Jr, 27-30. Manchester: Manchester University Press, 2004.

Villani, Matteo. Cronica con la continuazione di Filippo Villani ed. Porta (Parma, 1995), 2 vols II, Book Nine, chapter XXXVIII, pp. 338-40(1359) in Popular Protest in Late Medieval Europe, ed. Samuel K. Chon Jr, 94-95 Manchester: Manchester University Press, 2004 